\title{
THE ULTRASTRUCTURE OF ARTICULAR CARTILAGE IN THE PRENATAL DOMESTIC CAT
}

\author{
D. HORKÝ \\ Department of Histology and Embryology \\ Faculty of Medicine, Masaryk University, 66244 Brno
}

Received March 23, 1993

\begin{abstract}
Horký D.: The Ultrastructure of Articular Cartilage in the Prenatal Domestic Cat. Acta vet. Brno, 62, 1993: 115-120.

The articular cartilage of 11 foetuses of the domestic cat, both males and females, was studied at 30, 40 and 48 days after fertilization. The tissue samples were collected from the femoral heads and processed by standard methods for observation by light and transmission electron microscopy.

In the period studied, the cartilage surface was covered with the chondrosynovial membrane. Bundles of aperiodic filaments were seen under as well as on the cartilage surface, being a part of the membrane structure. Collagen fibrils, found in low numbers, were running in various directions in the ground amorphous substance.

Chondrocytes in the surface layer were situated in two parallel rows. They had oval or spindle-like shapes, contained large nuclei and few organelles in the cytoplasm. Glycogen and lipid droplets occurred rarely. Occasional chondrocytes with atypical cilia were seen in the surface and deep layers. Of interest was a finding of erythrocytes in the intercellular matrix of the deep layer.
\end{abstract}

Ultrastructure, articular cartilage, domestic cat, prenatal development

The submicroscopic structure of adult articular cartilage has been know since 1959 (Zelander) and light and electron microscopic studies have provided a great deal of detailed information in various mammalian species, such as rabbit (Davies et al. 1962; Barnett et al. 1963), mouse (Silberger et al. 1976), rat (Mark et al. 1989), dog (Lust et al. 1972; Wiltberger and Lust 1975; Fife 1989), cattle (Franzén 1981; Horký 1983, 1987; Jeffery et al. 1991; Neame et al. 1989; Kiefer et al. 1989), pig (Nakano et al. 1979; Bhatnagar et al. 1981; Horký 1989, 1991c) and man (Ghadially 1983; Horký 1980, 1991a,b; Bozděch et al. 1990).

The properties of cartilage have also been studied in relation to the surface configuration and in respect to its ability to resist enormous loads. Much attention has been paid to the cajacity of cartilage to reduce the friction of articular surfaces, which depends on the high lubricating action of synovial fluid and the smoothness of the articular surfaces themselves. The resistance of cartilage to pressure is based on the structure and distribution of the intercellular matrix involving two components (Weiss et al. 1968; Bloebaum and Wilson 1980, Horký 1980; Clark 1990). Chondrocytes play only a minor role in the mechanics of articular movement but are largely involved in the synthesis of intercellular matrix which is responsible for the mechanical operations of cartilage, and for facilitating the gliding and lubricating of adjoining surfaces ( $\mathrm{Ma}$ roudas 1973; Cappuis et al. 1983; Palmoski and Bradt 1984; Swann 1985; Broom 1986; Hills 1989, 1990 and others).

The studies mentioned above were generally concerned with adult individuals, only occasionally has the ultrastructure of articular cartilage been investigated before birth as, for instance, by Horky $(1989,1991 \mathrm{a}, \mathrm{b}, \mathrm{c})$ in the prenatal pig and human embryo. Since in the domestic cat, no data on the submicroscopic structure of articular cartilage in the prenatal period have ever been reported, it was decided to undertake this study and supply them. 


\section{Materials and Methods}

Samples of feline articular cartilage for examination by light and transmission electron microscopy were collected from 3 foetuses at 30 days, 4 at 40 days and 4 at 48 days after fertilization. For transmission electron microscopy, strips of the tissue $(1 \times 1 \times 2 \mathrm{~mm})$ were immediately fixed in $300 \mathrm{mmol} / 1$ or $400 \mathrm{mmol} / 1$ glutaraldehyde in phosphate buffer $\mathrm{pH} 7.4$ for $240 \mathrm{~min}$. Then they

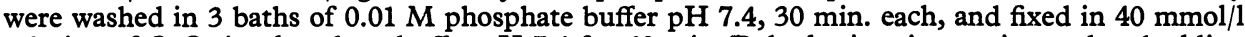
solution of $\mathrm{OsO}_{4}$ in phosphate buffer $\mathrm{pH} 7.4$ for $60 \mathrm{~min}$. Dehydration, immersion and embedding in Durcupan ACM were carried out by standard methods. Ultrathin sections were cut in a Reichert Ultracut ultramicrotome and stained with lead citrate alone or uranyl acetate followed by lead citrate. The specimens were studied and photographed in a Tesla BS 500 electron microscope. The blocks with embedded material were also used for cutting semithin sections which, after staining with methylene blue and Azure II, were viewed in a light microscope.

\section{Results}

The submicroscopic structure of articular cartilage, over the whole series of observations, did not show substantial differences associated with foetal age. The characteristics of this specialized tissue, as described in the following study, will therefore be reported as relating to the whole period (30 to 48 days after fertilization), unless otherwise stated.

\section{Ultrastructure of the surface layer}

Chondrocytes of this layer were elongated, spindle-shaped cells, $8-10 \times$ $3-5 \mu \mathrm{m}$ in size, lying in a single or in two parallel rows (Plate I., Fig. 1). They usually included an oval nucleus, $5-7 \times 2-3 \mu \mathrm{m}$ large. The shape of the nucleus matched that of the cell with great precision.

Nuclear chromatin was arranged into an almost confluent layer of karyosomes adjancent to the nuclear envelope, with a few others irregularly distributed over a section through the nucleus (Plates I., II., Figs 1,2). A nucleolus of reticular type surrounded with perinuclear chromatin was a frequent finding.

The cytoplasm presented as a narrow band around the nucleus. It contained short cisternae of the granular endoplasmic reticulum rich in ribosomes, a small Golgi apparatus, occasional mitochondria of normal appearance and numerous vesicular structures, probably derived from pinocytotic vesicles (Plate II., Fig. 2).

At 48 days after fertilization, the surface layer chondrocytes showed atypical cilia (Fig. 2). They also contained lipid droplets (Fig. 1) but no glycogen.

The intercellular matrix consisted of an abundant ground amorphous substance with fine collagen fibres running in various direction. Only the superficial fibres were arranged parallel to the cartilage surface (Fig. 1). Together with aperiodic fibrils (Plates II., III., Figs 2, 3) they gave rise to a thick boundary layer (Figs $1,2)$. At the boundary with the articular cavity, aperiodic fibrils occurred in bundles, several $\mu \mathrm{m}$ long, which, in some pictures, were seen with a thin coating of the ground amorphous substance (Plate III., Fig. 4).

\section{Ultrastructure of the middle layer}

The middle layer chondrocytes were oval to elongated cells, $10-12 \mu \mathrm{m}$ on the long axis. The nucleus had a dense appearance and chromatin aggregated into a number of karyosomes. A nucleolus of reticular type was a regular finding (Plate IV., Fig. 5).

Compared to the surface layer chondrocytes, the cytoplasm in these cells was found in greater amounts. The granular endoplasmic reticulum was well deve- 
loped with numerous flat cisternae and vesicles rich in ribosomes (Fig. 5). All these structures were filled with medium-osmiophilic material. The Golgi apparatus, with its normal appearance, was usually found near the nucleus. Amongst the endoplasmic reticulum cisternae there were numerous round mitochondria showing abundant cristae (Fig. 5). Lysosomes and transport vacuoles were observed only occasionally (Fig. 5).

The cytoplasm sent out several short projections into the pericellular matrix which, by day 40 , had been developed (Fig. 5). The intercellular matrix at that period was characterized by short collagen fibrils and abundant ground amorphous substance.

\section{Ultrastructure of the deep layer}

The deep layer chondrocytes were relatively small cells, about $6 \times 4 \mu \mathrm{m}$ in size, oval to round in shape, usually placed in columns. They occurred either in pairs or singly in lacunae of pericellular matrix (Plate VI., Fig. 7). The nucleus, rich in chromatin, was up to $3-4 \mu \mathrm{m}$ in size. Nucleoli were a rare finding (Fig. 7).

The cytoplasm was found in distinctly lower amounts than in the middle layer chondrocytes. The granular endoplasmic reticulum was characterized by infrequent flat cisternae filled with medium-osmiophilic material (Fig. 7). Mitochondria were few in number and the Golgi apparatus consisted only of a few flat smooth cisternae (Fig. 7). The cytoplasm of some chondrocytes showed the presence of pinocytotic vesicles and transport vacuoles. Occasional empty regions were obviously left where glycogen had been washed out (Fig. 7).

The cytoplasm was observed to send out occasional projections into the surrounding pericellular matrix. Some projections were running through lacunae reaching, with their ends, the intercellular matrix. Cilia, which were an exceptional finding, were first noticed in these cells at 48 days after fertilization (Plate V., Fig. 6).

An interesting finding was the presence of erythrocytes in the intercellular matrix of this layer at day 40 . Near them, sections through cytoplasmic projections of articular cells and through bundles of collagen fibrils could be seen. The erythrocytes were without signs of any damage (Fig. 7).

\section{Discussion}

The present observations have showed that articular cartilage undergoes more or less the same changes in feline foetuses as in other mammalian species (Horký $1980,1983,1986,1987,1989,1991 \mathrm{a}, \mathrm{b}, \mathrm{c})$.

The most important structure for the future function of cartilage in the synovial joint is the surface layer. The middle and deep layers are responsible for the synthesis of the intercellular matrix, and for resistance to pressure and the distribution of this pressure on the subchondral bone.

The architecture of the surface layer significantly affects the gliding properties of cartilage and, by reducing friction in the joint, ensures smooth movement. The most important part of the surface layer is its boundary coating, called the chondrosynovial membrane. This has been described by Wolf (1946, 1969, 1975), and McConaill (1951), who observed the membrane by light microscopy and termed it the "lamina splendens". Based on these observations, the 
authors believed it to be a layer of hyaluronic acid. Later, with the use of electron microscopy, it has been demonstrated that the membrane consists of fine aperiodic fibrils, or bundles of such fibrils, and a ground amorphous substance. The thickness of the membrane varies even in one and the same joint of one individual. Generally, it depends on the kind of joint, the site of sample collection and the individual's age. In this respect the present results are in agreement with those published by Weiss et al. (1968) and Meachim and Stockwell (1973) for human cartilage. To the greatest extent, however, the thickness of the membrane depends on the individual's age. From earlier results (Horký 1991a, b), the thickness of this boundary layer in newborn animals is about $0.5 \mu \mathrm{m}$. In the prenatal feline cartilage studied here, the boundary layer did not exceed the thickness stated above. Its composition of aperiodic fibrils, or bundles of such fibrils, lying under as well as on the cartilage surface was in agreement with the previous findings by transmission and scanning electron microscopy (Horký $1980,1983,1986,1987,1991 a, b, c)$ and with the latest data reported by Giles (1992).

The chondrocytes in the middle and deep layers were arranged in the normal way. The intercellular matrix had a uniform appearance and, similar to other described mammalian species before birth, consisted of short collagen fibrils running in various directions and of an abundant ground amorphous substance (Bozděch et al. 1990; Clark 1990; Hills 1990). Formation of the pericellular matrix in these layers was observed only in some chondrocytes.

As for cilia, these were, in agreement with the literature, a very rare finding although, as reported by Wilsman and Fletcher (1978), Ghadially (1983) and Vidimov and Vasilev (1985), they may be more frequent in the developing organism. Cilia have been described in the chondrocytes of mice, rabbits, cattle and man (Scherft and Daems 1967; Stockwell and Meachim 1979; Horký 1983). These cilia, however, have usually had an atypical appearance including an altered structure of the basal body and a pattern of $9+0$ pairs of microtubules (Wilsman 1978).

\section{Ultrastruktura kloubní chrupavky kočky v prenatálním období}

Byla studována artikulárni chrupavka 11 fetů kočky obojího pohlaví stáří 30, 40 a 48 dní po oplození. Pro účely světelné, transmisní a rastrovací elektronové mikroskopie byla odebírána chrupavka $\mathrm{z}$ kyčelního kloubu a zpracována obvyklým způsobem.

$\mathrm{Na}$ povrchu chrupavky je ve sledovaném období již vytvořena chondrosynoviální membrána. Svazečky aperiodických filament jsou uloženy jednak pod povrchem, jednak na povrchu chrupavky a podílejí se na stavbě membrány. Kolagenní fibrily se vyskytují $\mathrm{v}$ malém počtu a probíhají $\mathrm{v}$ hojné základní hmotě různými směry.

Chondrocyty jsou $\mathrm{v}$ povrchové vrstvě uloženy zpravidla ve dvou řadách nad sebou. Mají oválný až vřetenovitě protáhlý tvar. Obsahují velké jádro, v cytoplasmě jsou uloženy málo početné organely. Glykogen a tukové kapénky jsme nalezli vzácně. Některé chondrocyty obsahovaly atypické cilie, které jsme pozorovali ojediněle $\mathrm{v}$ buňkách povrchové a hluboké vrstvy. Neobvyklým nálezem $\mathrm{v}$ mezibuněçné hmotě hluboké vrstvy kloubnni chrupavky byly erytrocyty. 


\section{Ультрастрүктүра сүставного хряща кошки в предродовой период}

Изучали артикулярный хрящ 11 плодов кошки обоих полов в возрасте 30,40 и 48 суток после оплодотворения. Для световой, трансмиссионной и растровой электронной микроскопии получали хрящ тазобедренного сүстава и обрабатывали его обычным способом.

На поверхности хряща в исследүемый период создана хондросиновиальная мембрана. Пүчки апериодических нитей расположены под поверхностью, а также на поверхности хряща и участвуют в строении мембраны. Клейдающие фибриллы встречаются в небольшом количестве и в многочисленной основной массе проходят в разном направлении.

Хондроциты в поверхностном слое расположены, как правило, в вертикально размещенных двух рядах. Они отличаются овальной, даже веретенообразно продолговатой формой и содержат большое ядро. В цитоплазме расположены немногочисленные органеллы. Гликоген и жировые капельки встречались редко. Некоторые хондроциты содержали атипичные реснички, наблюдаемые нами в отдельных случаях в клетках поверхностного и глубокого слоев. Необычной находкой в межклеточной массе глубокого слоя суставного хряща стали эритроциты.

\section{References}

BARNETT, C. H. - COCHRANE, W.-PALFREY, A. J.: Age changes in articular cartilage of rabbits. Ann. rheum. Dis., 22, 1963: 389-400

BHATNAGAR, R. - CHRISTIAN, R. G. - NAKANO, T. - AHERNE, F. X. - THOMPSON, J. R.: Age related changes and osteochondrosis in swine articular and epiphyseal cartilage: light and electron microscopy. Can. J. Comp. Med., 45, 1981: 188-195

BLOEBAUM, R. D.-WILSON, A. S.: The morphology of the surface of articular cartilage in adult rats. J. Anat., 131/2, 1980: 333-346

BOZDËCH, Z. - HORKYY, D. - JANECEK, M.: Chrupavka a synoviální tkán lidského kloubu. Acta Fak. med. Univ. Masaryk. Brunensis 1990, 1-150

BROOM, N. D.: The collagenous architecture of articular cartilage- a synthesis of ultrastructure and mechanical function. J. Rheumatol., 13, 1986: 142-152

CLARK, J. M.: The organization of collagen fibrils in the superficial zones of articular cartilage. J. Anat., 171, 1990: 117-130

DAVIES, D. V.-BARNETT, C. H. - COCHRANE, W.-PALFREY, A. J.: Electron microscopy of articular cartilage in the young adult rabbit. Ann. rheum. Dis., 21, 1962: 11-22

FRANZÉN, A.: Variations in the composition of bovine hip articular cartilage with distance from articular surface. Biochem. J., 195, 1981: 535-543

GHADIALLY, F. N.: Fine structure of synovial joints. Butterworths, London, 1983: 42-80

GILES, L. G. F.: The surface lamina of the articular cartilage of human zygoapophyseal joint. Anat. Rec., 233, 1992: 350-356

HILLS, B. A.: Oligolamellar nature of the articular surface. J. Rheumatol., 17, 1990: 340 to 356

HILLS, B. A.: Oligolamellar lubrication of joints by surface active phospholipid J. Rheumatol., 16, 1989: 82-91

HORKY, D.: Submicroscopic structure of the human joint cartilage. Acta vet. Brno, 49, 1980: $145-176$

HORKY, D.: Ontogenic development of the ultrastructure of bovine joint cartilage. Acta vet. Brno, 52, 1983: 103-130

HORKÝ, D.: Ultrastructure of bovine articular cartilage between weeks 8 and 23 of prenatal development. Acta vet. Brno, 55, 1986: 227-246

HORKÝ, D.: Submicroscopic structure of bovine articular cartilage in prenatal and early postnatal period. Acta vet. Brno, 56, 1987; 3-18 
HORKÝ, D.: The ultrastructure of articular cartilage in the prenatal pig. Acta vet. Brno, 58, 1989: $143-174$

HORKÝ, D.: Submicroscopic structure of articular cartilage in human embrya six to eleven weeks old. Acta vet. Brno, 60, 1991a: 15-30

HORKÝ, D.: Submicroscopic structure of human articular cartilage in the period between 19 to 38 weeks after fertilization. Acta vet. Brno, 60, 1991b: 111-126

HORKÝ, D.: The submicroscopic structure of articular cartilage in swine in the early postnatal period. Acta vet. Brno, 60, 1991c: 323-334

CHAPPUIS, J. - SHERMAN, I. A. - NEUMANN, A. W.: Surface tension of animal cartilage as it relates to function in joints. Ann. Biomend. Eng., 11, 1983: 435-451

JEFFERY, A. K. - BLUNN, G. W.-ARCHER, C. W.-BENTLEY, G.: Three-dimensional collagen architecture in bovine articular cartilage. J. Bone Jt. Surg. B., 73, 1991: 795-801

KIEFER, G. N. - SUNDBY, K. - McALLISTER, D. - SHRIVE, N. G. - FRANK, C. B. LAM, T. - SCHACHAR, N. S.: The effect of cryopreservation on the biomechanical behavior of bovine articular cartilage. J. Orthop. Res., 7, 1989: 494-502

LUST, G. - PRONSKY, W. - SHERMAN, D.: Biochemical and ultrastructural observation in normal and degenerative canine articular cartilage. Am. J. Vet. Res., 33, 1972: $2429-2440$

MARK, M. P. - BUTLER, W. T. - RUCH, J. V.: Transient expression of a chondroitin sulfate-related epitope during cartilage histomorphogenesis in the axial skeleton of fetal rats. Develop. Bio., 133, 1989: 475-489

MAROUDAS, A.: Physico-chemical properties of articular cartilage. I: Adult articular cartilage. Ed.: M.A.R. Freeman, Alden Press, Oxford, Great Britain, 1973: 131-170

McCONAILL, M. A.: The movements of bones and joints. The mechanical structure of articulating cartilage. J. Bone Jt. Surg., 33 B, 1951: 251-257

MEACHIM, G. - STOCKWELL, R. A.: Adult articular cartilage. In: Adult articular cartilage. Ed.: M.A.R. Freeman, Alden Press, Oxford, Great Britain, 1973: 20-129

NAKANO, T. - AHERNE, F. X. - THOMPSON, J. R.: Changes in swine knee articular during growth. Can. J. Anim. Sci., 59, 1979: 167-179

NEAME, P. J.-CHOI, H. U.-ROSENBERG, L. C.: The primary structure of the core protein of the small, leucine-rich proteoglycan (PG I) from bovine articular cartilage. J. Biol. Chem., 264, 1989: 8 646-8653

PALMOSKI, M. J. - BRANDT, K. D.: Effects of static and cyclic compressive loading on articular cartilage plugs in vitro. Arthritis Rheum., 27, 1984: 675-682

SCHERFT, J. P.-DAEMS, W. Th.: Single cilia in chondrocytes. J. Ultrastruct. Res., 19, 1967: 546-555

SILBERGER, R. - HASLER, M. - LESKER, P.: Ultrastructure of articular cartilage of achondroplastic mice. Acta Anat. (Basel), 96, 1976: 162-175

STOCKWELL. R. A. - MEACHIM, G.: The chondrocytes. In: Adult articular cartilage. 2nd edition. Ed.: M.A.R. Freeman, London, Pitman Medical 1973

SWANN, D. A. - SILVER, F. H. - SLAYTER, H. S.: The molecular structure and lubricating activity of lubricin isolated from bovine and human synovial fluids. Biochem. J., 225, 1985: 195-201

VIDINOV, N. - VASILEV, V.: Cilia in rat articular chondrocytes. Anat. Anz. Jena, 158, 1985: $51-55$

WEISS, C.-ROSENBERG, L.-HELFET, A. J.: An ultrastructural study of normal young adult human articular cartilage. J. Bone Jt. Surg., 50A, 1968: 663-674

WILSMAN. N. J.: Cilia of adult canine articular chondrocytes. J. Ultrastruct. Res., 64, 1978: $270-286$

WILSMAN, N. J. - FLETCHER, T. F.: Cilia of neonatal articular chondrocytes incidence and morphology. Anat. Rec., 190, 1978: 871-889

WILTBERGER, H.-LUST, G.: Ultrastructure of canine articular cartilage: comparison of normal and degenerative (osteoarthritic) hip joints. Am. J. Vet. Res., 36, 1975: 727-740

WOLF, J.: Chondrosynoviální blanka a její význam. Sborník lékařský Praha, 48, 1946: 277-286

WOLF, J.: Chondrosynovial membrane serving as joint cavity lining with a sliding and barrier function. Folia Morphol. (Prague), 17, 1969: 291-308

WOLF, J.: Function of chondral membrane on surface of articular cartilage from point of view of its mechanical resistance. Folia Morphol. (Prague), 23, 1975: 77-87

ZELANDER, T.: Ultrastructure of articular cartilage. Z. Zellforsch., 49, 1959: 720-738 
Horký, D.: The Ultrastructure of Articular Cartilage... pp. 115-120

Plate I.

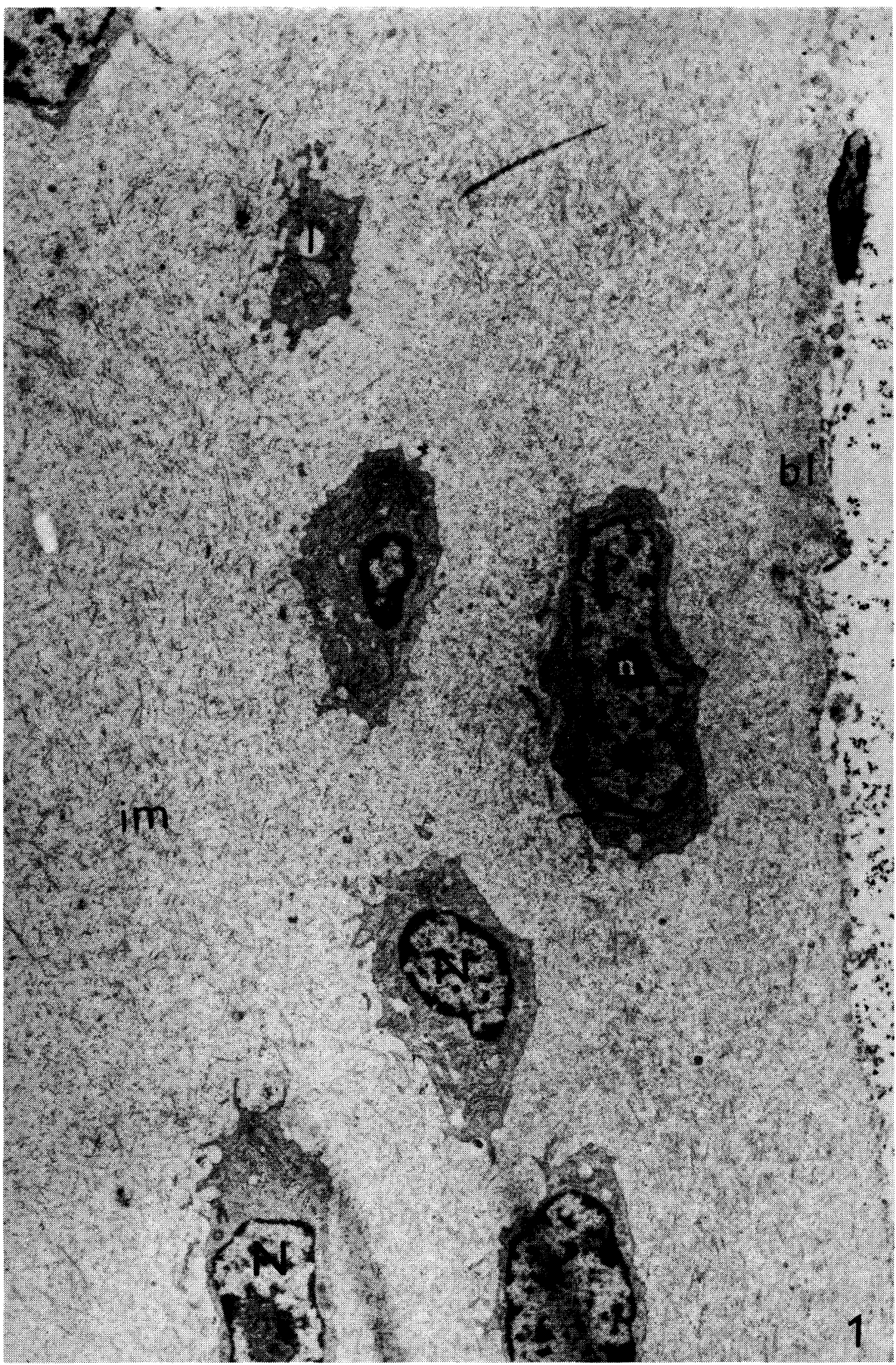

Fig. 1.: Surface and middle layers of feline articular cartilage at 48 days after fertilization. Nucleus (N), nucleolus (n), lipid droplets (1), boundary layer (bl). Intercellular matrix (im). $\times 4,100$. 
Plate II.

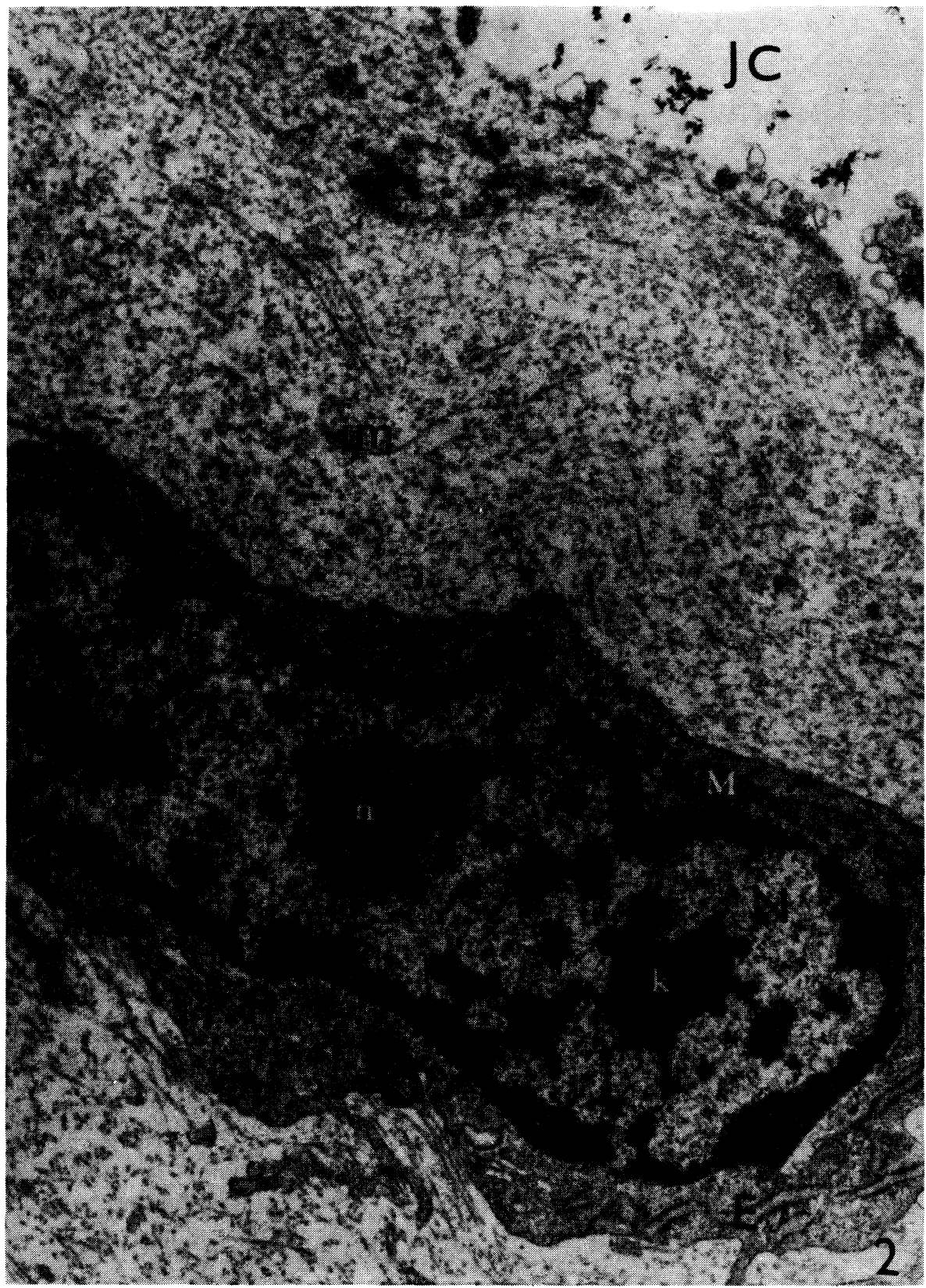

Fig. 2: A chondrocyte of the surface layer of feline articular cartilage at 48 days after fertilization. Nucleus (N), nucleolus (n), karyosomes (k), mitochondria (M), granular endoplasmic reticulum (E), atypical cilium (C). Intercellular matrix (im), joint cavity (JC). $\times 16,000$. 


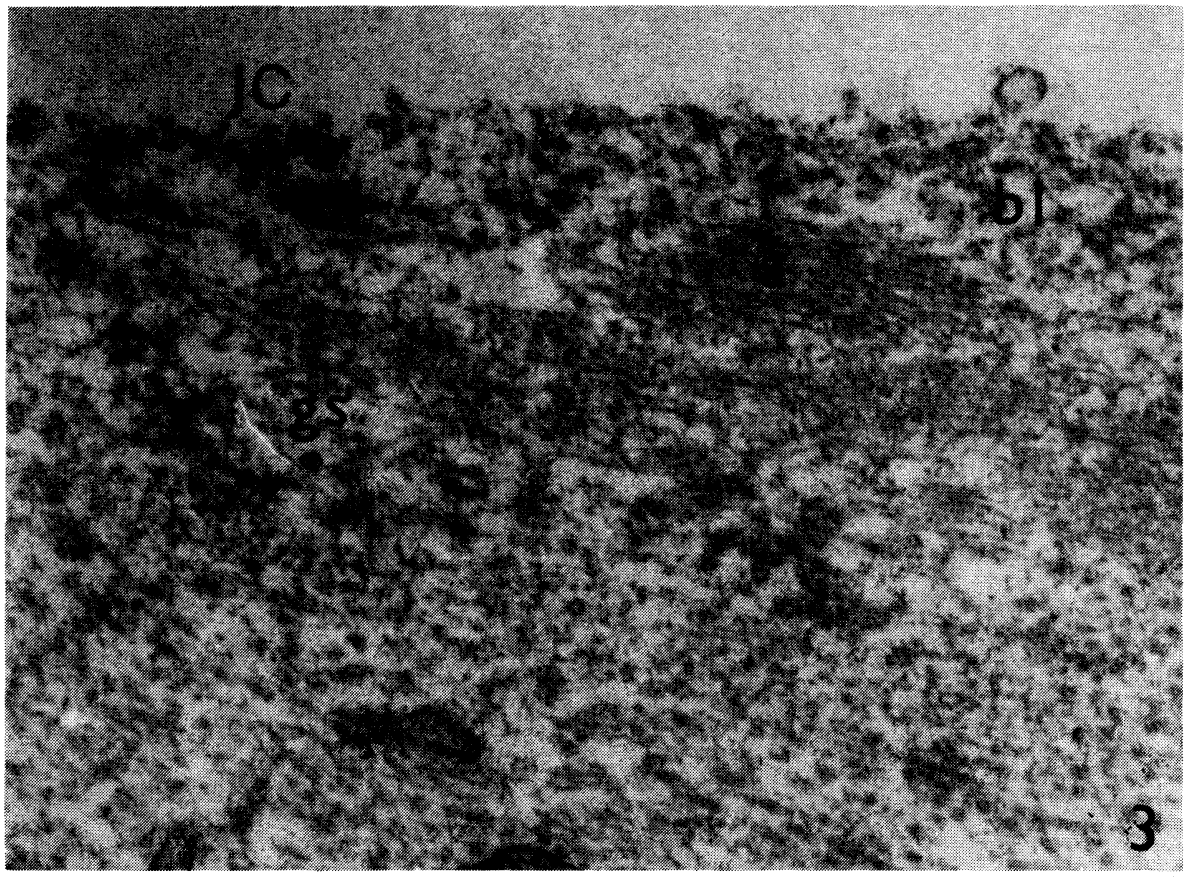

Fig. 3: Boundary layer (bl) of feline articular cartilage at 40 days after fertilization. Bundles of aperiodic filaments (a), collagen fibrils (c), ground amorphous substance (gs), joint cavity (JC). $\times 20,000$.

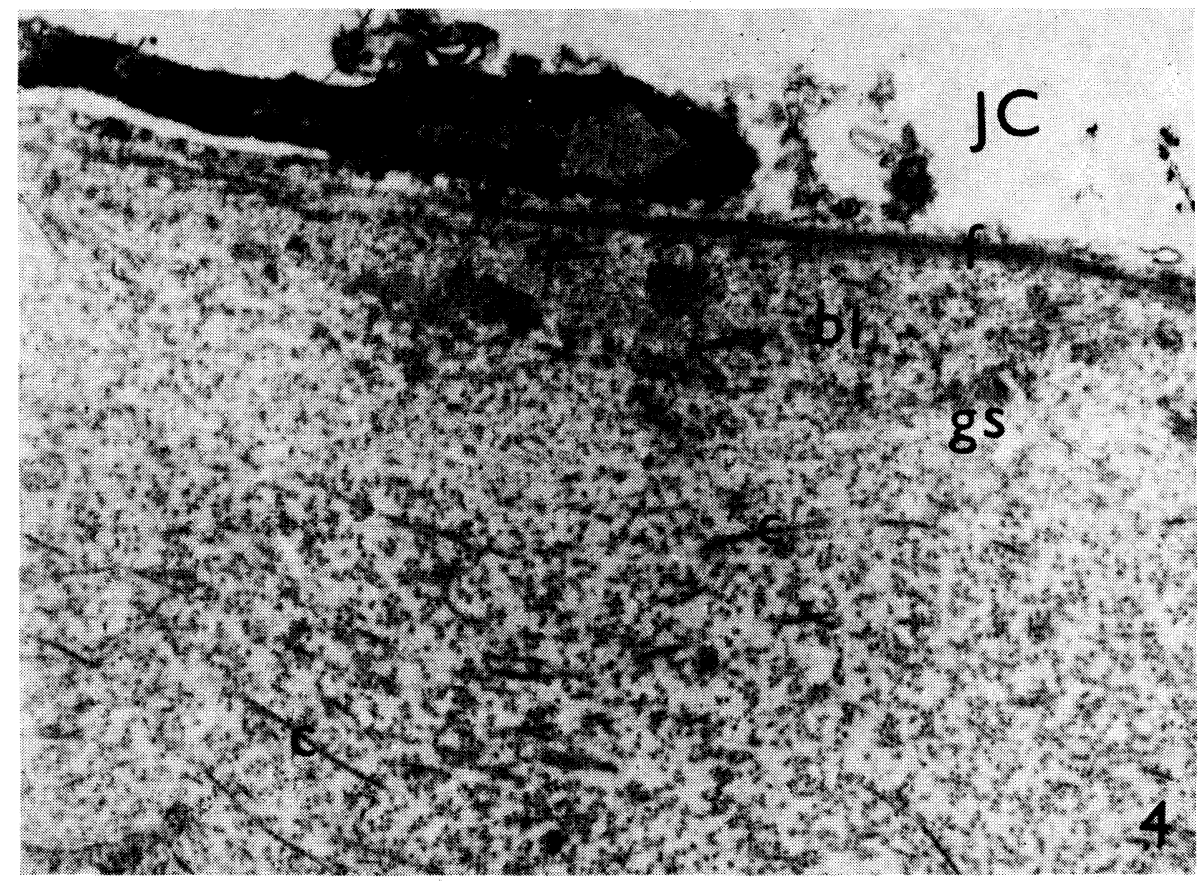

Fig. 4: Boundary layer (bl) of feline articular cartilage at 48 days after fertilization. Bundles of aperiodic filaments (a) under and on the surface at the boundary (f) with the joint cavity (JC). Collagen fibrils (c), ground amorphous substance 


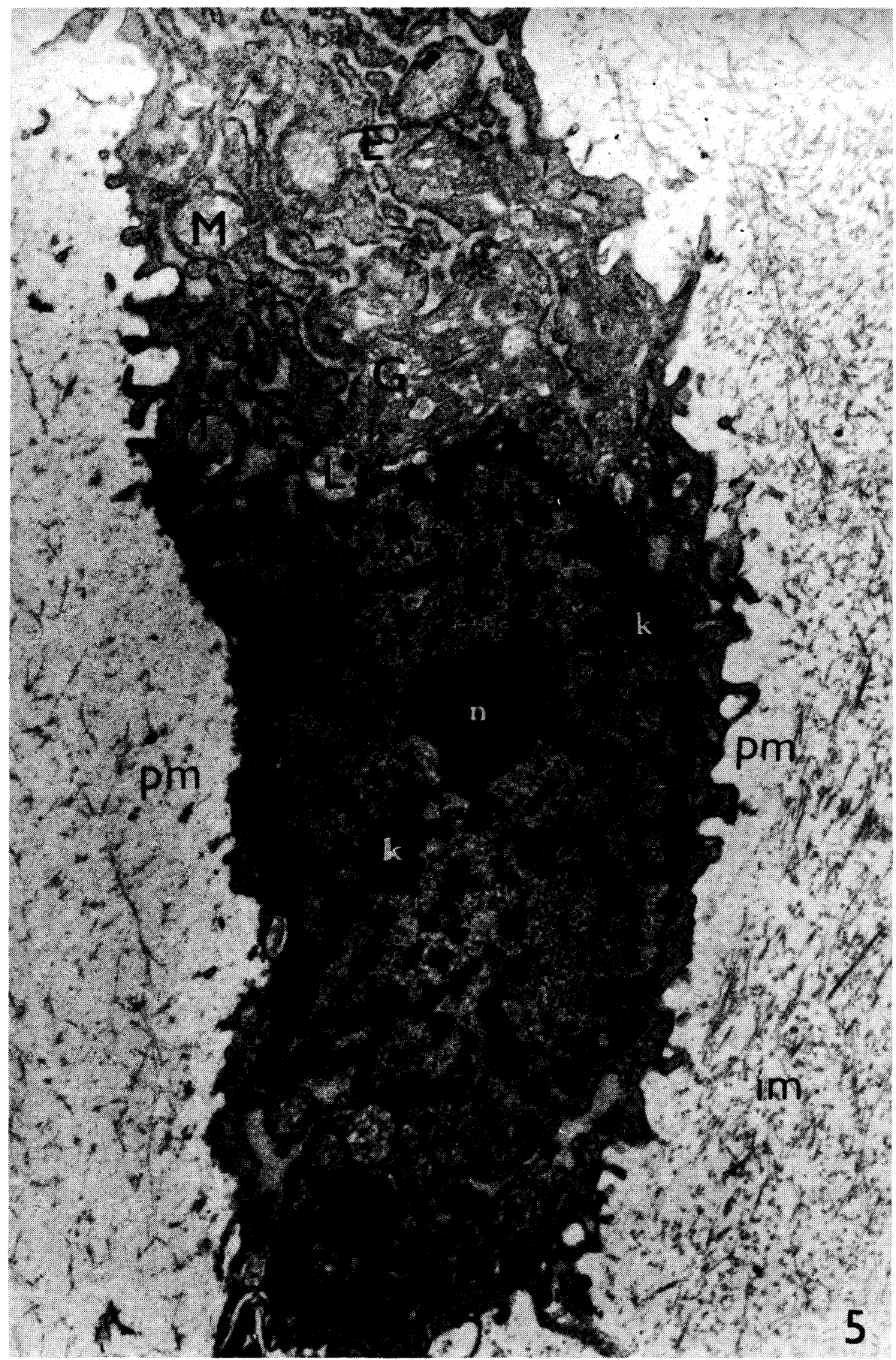

Fig. 5: Chondrocytes of the middle layer of feline articular cartilage at 40 days after fertilization. Nucleus (N), nucleolus (n), numerous karyosomes (k). Mitochondria (M), numerous cisternae of the granular endoplasmic reticulum (E) with medium-osmiophilic material. Lysosome (L), transport vacuole $(\mathrm{T})$, Golgi apparatus (G). Pericellular matrix (pm), intercellular matrix (im). $\times 16.000$. 


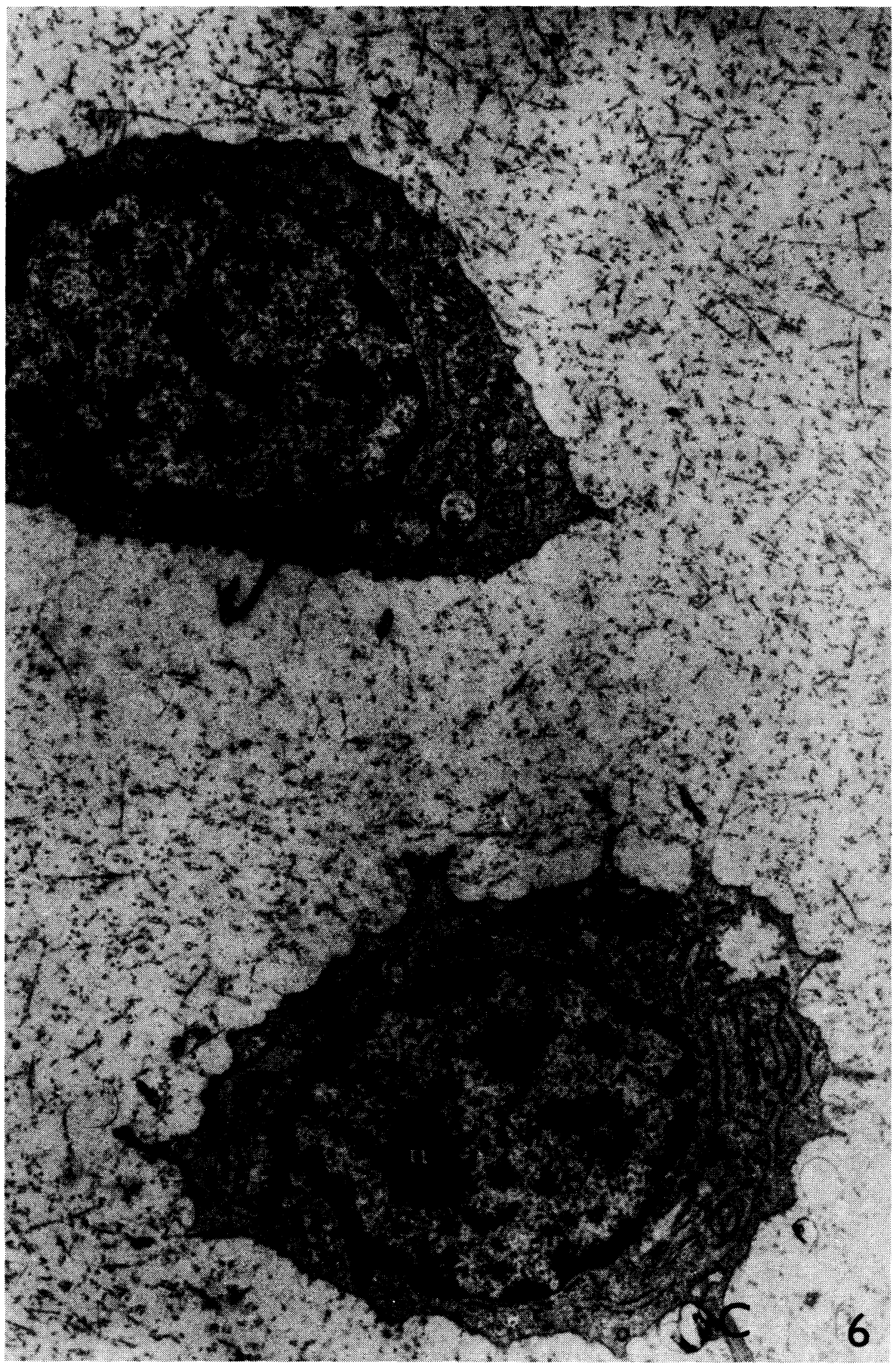

Fig. 6: Chondrocytes of the deep layer of feline articular cartilage at 48 days. Nucleus $(\mathrm{N})$, nucleolus $(\mathrm{m})$, mitochondria $(\mathrm{M})$, cisternae of the granular endoplasmic reticulum (E) with medium-osmiophilic material. Atypical cilia (C). $\times 12,000$. 


\section{Plate VI.}

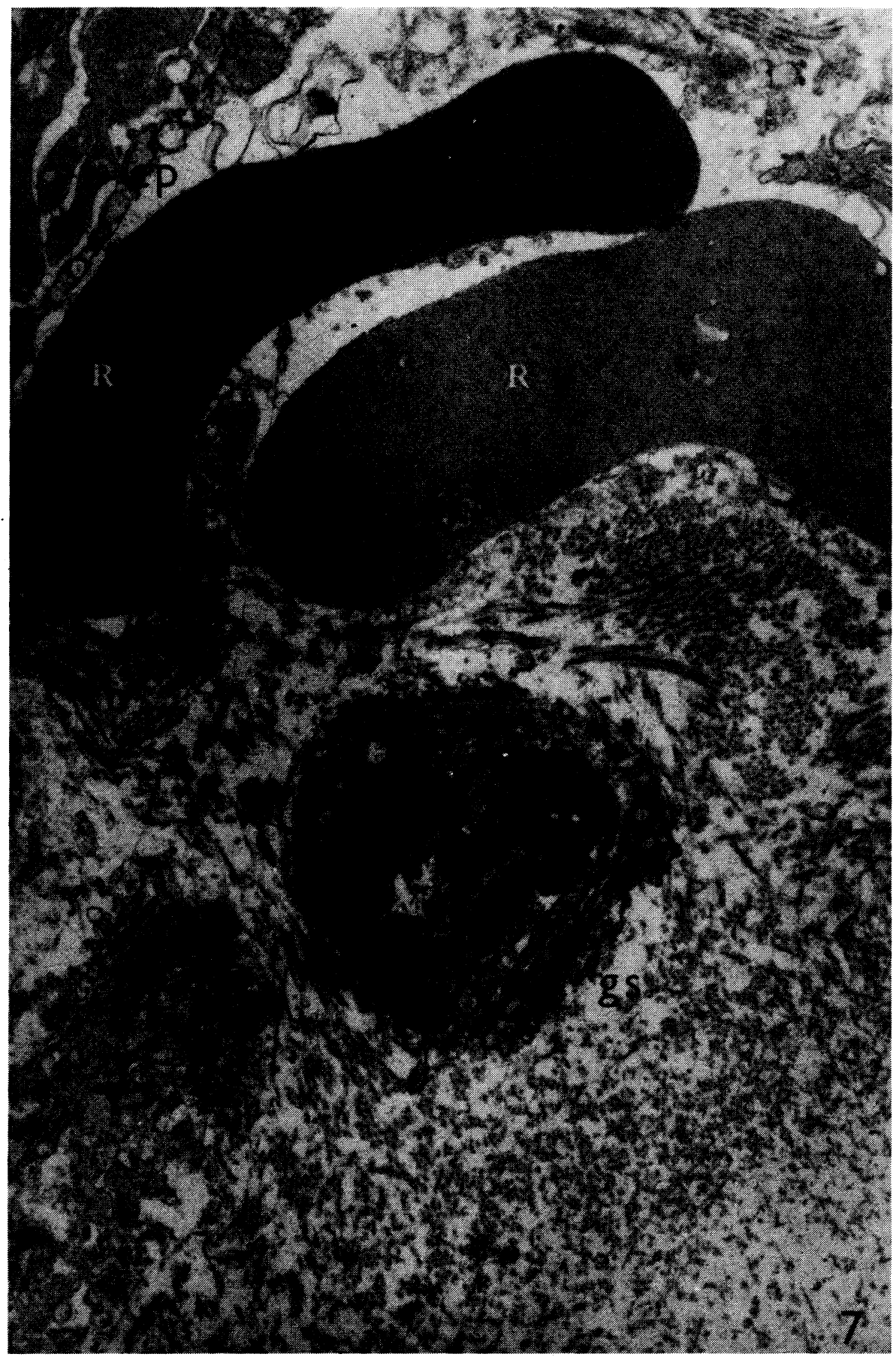

Fig. 7: Erythrocytes (R) in the intercellular matrix of the deep layer of feline articular cartilage at 40 days after fertilization. Bundles of collagen fibrils (c), cell projections (cp), ground amorphous substance (gs). $\times 12,000$. 